\title{
A Literature Review Related to the Modern Harvesting - Forwarding Equipment and the Main Topics Concern of the Research Community
}

\author{
Andrei APĂFĂIAN ${ }^{1)}$, Vasile BOGHIAN ${ }^{1)}$, Alexandru BRATU ${ }^{1)}$ \\ 1) Department of Forest Engineering, Forest Management Planning and Terrestrial Measurements. \\ Transilvania University of Brasov, Romania. \\ ${ }^{*}$ Corresponding author, e-mail: andrei.apafaian@unitbv.ro
}

BulletinUASVM Horticulture 72(1) / 2015

Print ISSN 1843-5254, Electronic ISSN 1843-5394

DOI:10.15835/buasvmcn-hort:10658

\begin{abstract}
A literature review on harvester and forwarder equipment was conducted using the open access international scientific databases. The aims of this study were to evaluate the main interests of different research topics elaborated in 28 countries around the world in the last 23 years. The time span of the main articles ranged from the beginning of the year 1990 to end of 2012. The evolution trend of research topics was analyzed for this time period in order to relate them to possible future research directions in Romania. Most of the used literature was extracted mainly from scientific journals and conference proceedings, summing up a total of 105 references that were further analyzed. As expected, the synthesis of the references, pointed out that most of the interests and attention of the scientists has been given to productivity, costs and time expenditure on one hand, followed by studies on soil impact, environment and tree damage on the other hand. Topics referring to fuel-lubricants consumption and computer simulations didn't had the same impact among the researched literature, accounting for the smallest number of the cited articles. The obtained results will fill in the gap in future research by using scientific approaches particular to the Romanian conditions.
\end{abstract}

Keywords: forwarder, harvester, international database, open access, synthesis.
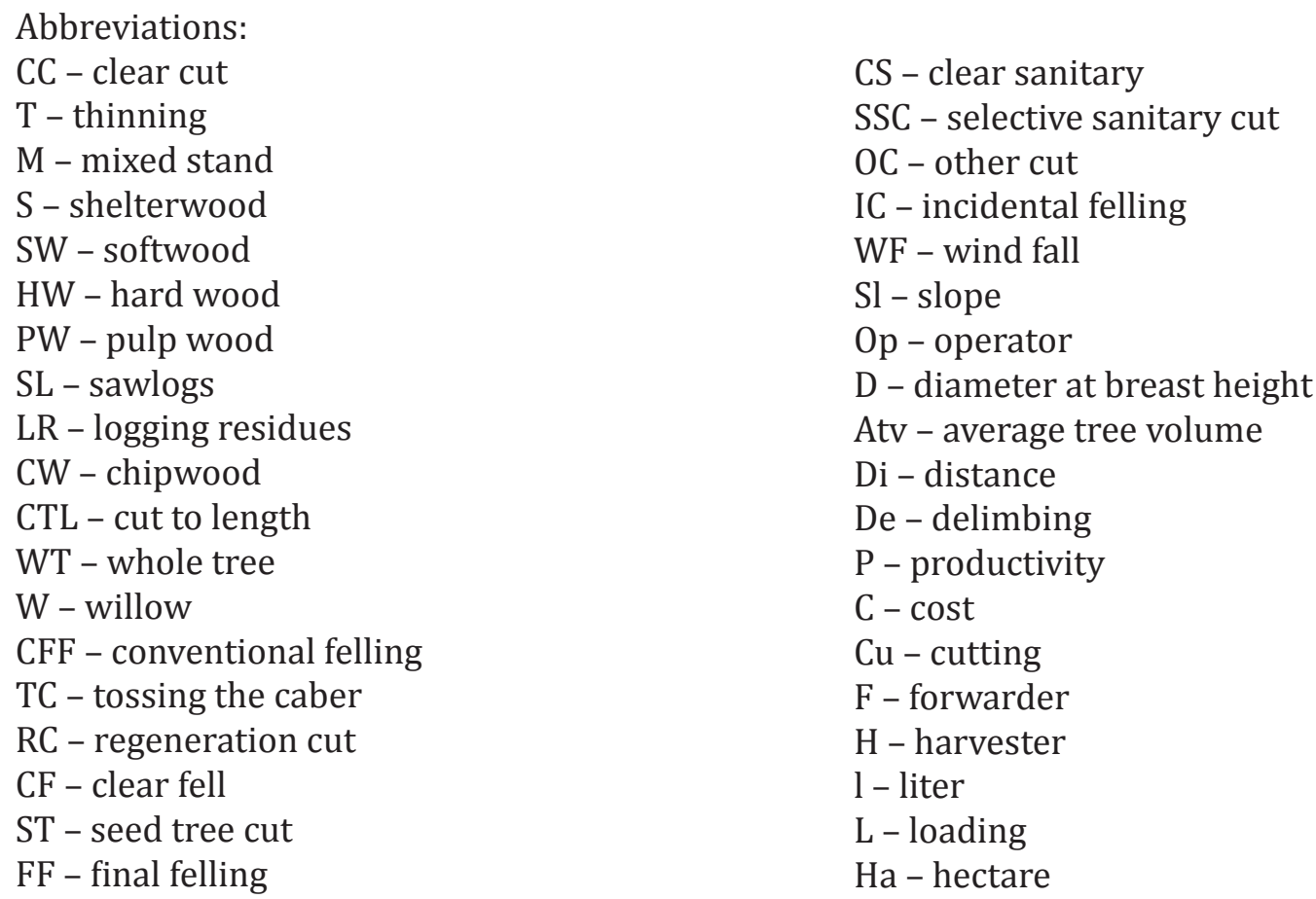


$$
\begin{aligned}
& \text { L - loading } \\
& \text { UL - unloading } \\
& \text { Hr - harvesting } \\
& \text { Fr - forwarding } \\
& \text { u.b - under bark } \\
& \text { Ho - productive working hour } \\
& \text { h - hour } \\
& \text { m - meters } \\
& \text { HW - harwarder } \\
& \text { Min - minutes } \\
& \text { WH - working hour } \\
& \text { Av - average volume }
\end{aligned}
$$

$\mathrm{Y}$ - yarder

MF - midfield

SR - skidroad

$\mathrm{SH}$ - scheduled hour

$\mathrm{T}$ - ton

LCA - life cycle analysis

ODT - oven dried tons

GT - green ton

SGH - single grip harvesters

DGH - double grip harvester

$\mathrm{E}_{15} / \mathrm{E}$ - effective hour with/ without 15 min. delays

\section{INTRODUCTION}

Timber harvesting in Romania is performed mostly by traditional equipment such as skidders and forest-fitted farm tractors. Lately, modern forestry machinery such as the harvesters and forwarders started to be introduced in Romania. However, little is known about harvester and forwarder equipment in Romania and one way to assess either the benefits or bottlenecks of a given new technology is to do an extensive literature review.

The present literature review is an attempt to analyze the main topics that concerned the international forestry community, and to reveal which were the most debated subjects and results. The interests of researchers will automatically emphasize the most important trends.

\section{MATERIALS AND METHODS}

This paper aimed to describe a concise view on harvesting and forwarding equipment carried out in the last 23 years (1990-2012), by analyzing the main topics addressed by the forest scientists. Furthermore, it tried to identify the gaps in knowledge and synthesize the new scientific approaches in order to improve the general view on research methods when dealing with such equipment.

The considered time span was so extended because we tried to analyze all the information that could be found on every available source, although the biggest and important percentage of the articles was after the year 2000. To search for the needed information the data bases given in Table 1 were investigated. All the inquired data bases belonged to the open access category, and they were used in order to review data that can be obtain without having to have an active subscription.

Each of the references was queried using the following keywords: harvester and forwarder, harvester, forwarder, cut-to-length harvester, hauling distances, soil damage forwarder, productivity, delays.

All the papers are written in English. All the main concerns regarding harvesting and forwarding were covered, some of them more than the others.

The research papers have been grouped into four sections with subsections as follows:

1. Productivity, time consumption, costs.

a. Productivity - this section describes the productivity in different cases for the harvester and forwarder.

b. Time consumption - this section describes the time spent for CTL technology and for loading short wood.

c. Costs - this section describes the value of the costs related to distance, management practices.

d. Delays - this section describes the delays that occurs in harvester operations

e. Loading - this section describes the loading phase made by the forwarder.

2. Fuel and lubricants consumption - this section describes the consumption related to hauling distance and mean tree diameter.

3. Tree damage and soil disturbance 
Tab. 1 Open access inquired databases

\begin{tabular}{cccc}
\hline $\begin{array}{c}\text { Int. Journal of } \\
\text { Forest Engineering }\end{array}$ & Forst und Technik Magazine & $\begin{array}{c}\text { Int. Mountain Logging and 11th } \\
\text { Pacific Symposium }\end{array}$ & $\begin{array}{c}\text { Investigation } \\
\text { agrariasistemas y } \\
\text { recursosforestales }\end{array}$ \\
\hline $\begin{array}{c}\text { Journal of Forest } \\
\text { Science }\end{array}$ & Forest product journal & PesquisaAgropecuáriaBrasileira & $\begin{array}{c}\text { PesquizaAgropecunaria } \\
\text { Tropical }\end{array}$ \\
\hline Silva Fennica & IUFRO & Bosque & JMHT \\
\hline $\begin{array}{c}\text { Croatian Journal of } \\
\text { Forest Engineering }\end{array}$ & AllgemeineForstZeitung & $\begin{array}{c}\text { Canadian Journal of Forest } \\
\text { Research }\end{array}$ & GozdarskiVestnik \\
\hline $\begin{array}{c}\text { Japanese Forest } \\
\text { Society and } \\
\text { Springer }\end{array}$ & Universities & $\begin{array}{c}\text { PraceInstytutuBadawczego } \\
\text { Leśnictwa }\end{array}$ & Advantage (FERIC) \\
\hline $\begin{array}{c}\text { European Journal } \\
\text { of Forest Research }\end{array}$ & ForstlicheForschungsBerichte & Mondo Macchina & $\begin{array}{c}\text { Proceedings of the } \\
\text { Austro2003 meeting }\end{array}$ \\
\hline $\begin{array}{c}\text { Forestry reports } \\
\text { Formec Croatia }\end{array}$ & $\begin{array}{c}\text { Forest ecology and } \\
\text { management }\end{array}$ & InTech Journal & U.S Dept. Of Agriculture \\
\hline $\begin{array}{c}\text { Forest research } \\
\text { instit. Of Canada }\end{array}$ & $\begin{array}{c}\text { Soil Science Society of } \\
\text { American Journal }\end{array}$ & Forsttechnischeinformationen & Formec Bulgaria \\
\hline Silva Fenica & Lesovedenie & Annals of forest science & Formec Austria \\
\hline
\end{tabular}

Tab. 2 Number of articles/abstracts per section

\begin{tabular}{cccccc}
\hline $\begin{array}{c}\text { Articles/ } \\
\text { Abstracts }\end{array}$ & $\begin{array}{c}\text { Productivity, time, cost, } \\
\text { delays, loading }\end{array}$ & Fuel & $\begin{array}{c}\text { Soil and tree } \\
\text { damage }\end{array}$ & $\begin{array}{c}\text { Computer } \\
\text { simulation }\end{array}$ & Total \\
\hline Articles & 40 & 5 & 26 & 6 & 76 \\
\hline Abstracts & 14 & 0 & 14 & 0 & 29 \\
\hline Total & 54 & 5 & 40 & 6 & 105 \\
\hline
\end{tabular}

a. Tree damage - this section describes the damages that occur after using the harvester and forwarder equipment.

b. Soil disturbance - this section describes the different actions that are causing damage to the soil and different methods to improve the negative effects.

4. Computer simulations - different approaches are developed with the help of informatics in order to asses some hypothesis

\section{RESULTS AND DISCUSSION}

The sections are composed from a total of 76 papers and 29 abstracts made by 235 authors from 28 different countries. The most debated section is "productivity" and "soil and tree damage" summing up $90 \%$ of the articles where categories like "fuel consumption" and "computer simulation" are representing the rest of $10 \%$.
Tab. 3 Source of the cited references

\begin{tabular}{cc}
\hline Source & Nr. of articles \\
\hline Journals & 72 \\
\hline Conference proceeding & 23 \\
\hline Research institute & 5 \\
\hline University research & 4 \\
\hline Report & 1 \\
\hline
\end{tabular}

The papers are mostly published in journals, conferences, research institutes, university environment and reports (Tab. 3). In our review we didn't included any books.

The main source of literature that is analyzed in this study, almost $86 \%$ comes from scientific journals and conference proceedings while the rest has a small proportion. 
For each section the articles are sorted in accordance to geographical region and publication date. The geographical grouping is mandatory to assess the "key-points" of each and every one of it and then to compare them in order to synthesize the similarities or differences. For each paper the research information has been summarized in accordance to type of forest, type of cut, stand characteristics in order to ease the analysis process.

\section{Time span and country distribution of the cited articles}

As it was expected the majority of the articles were written in countries that have a long tradition in using such equipment like the Nordic countries and U.S.A. (Fig. 1).

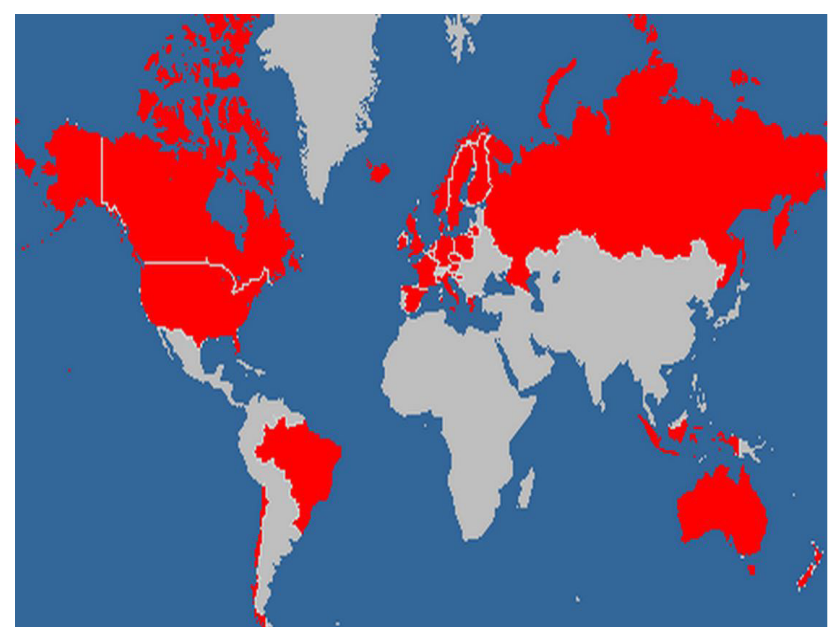

Fig.1 Researched geographical regions of the cited literature (www.douweosinga.com).
The references elapsing in time as well as their number in the given time period is shown in Fig. 2. We considered that calculating the mean of the number of articles per year would not be concluding given the significant differences which were observed in the period taken into study. Unfortunately, for the years 1993 and 2000 we didn't found any article in the open access databases.

\section{Analysis of the productivity, time consumption, costs \\ Productivity plays an essential role in} harvesting and forwarding operations and it is deeply related to time consumption and the involved costs. These three key words have a great importance in the stump to mill wood price. In this section the analysis of all the studies regarding the mentioned descriptors was made. A total of 54 references more than half of the 105 articles are composing this section. In those papers 78 descriptors (Tab. 4) are present.

As resulted from the table we can conclude that the descriptor productivity is present 41 times in the 54 articles. As predicted productivity is an important research topic all over the world.

Tab. 4 Number of descriptors in the references

\begin{tabular}{cc}
\hline Descriptor & Mentioned number \\
\hline Productivity & 41 \\
\hline Time consumption & 20 \\
\hline Cost & 17 \\
\hline Total & 78 \\
\hline
\end{tabular}

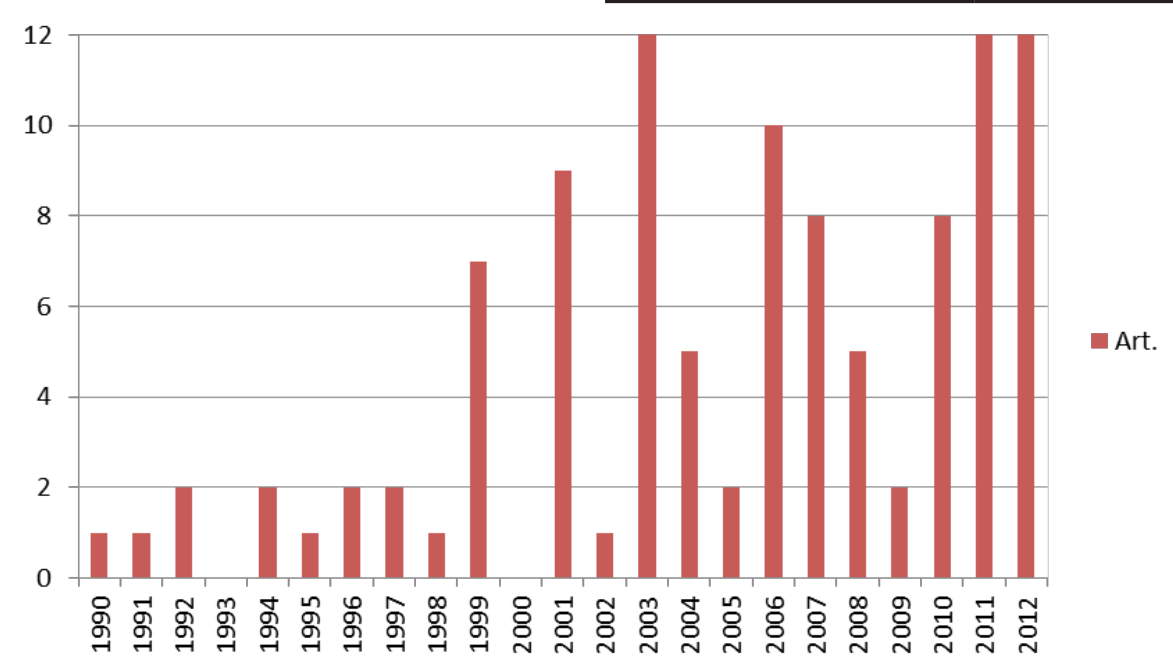

Fig. 2 Time distribution of the cited articles. 
Time consumption and cost have almost the same number summing up a total of 37 articles. The data from the cited literature is presented in Table 5.

North American studies accounted for a total of 11 references from the total. Thinning was studied in 5 references revealing a diameter from 24 to $26.9 \mathrm{~cm}$. The harvester productivity was $19.17 \mathrm{~m}^{3} /$ productive working hour or 39 to 55 trees / productive working hour in another study. For the forwarder productivity was 15.3 $\mathrm{m}^{3} / \mathrm{h}$ for a distance of $267 \mathrm{~m}$. In the case of a mixed stand the productivity was with $25 \%$ lower while the processed trees per hour remained the same. Harvesting costs varied from $4.46 \$ / \mathrm{m}^{3}$ in 1994 to $5.54 \$ / \mathrm{m}^{3}$ after 20 years. In the case of shelterwood cut productivity is slighter higher but with almost double the cost. Tree volume, stand density and distance are the main factors affecting productivity and cost. In the case of South America region only one study is present, showing that the effective work was $75.6 \%$ for harvester and $84.7 \%$ for the forwarder, the rest of the time is summing up downtime.

Nordic countries have been always the pioneers regarding the harvesting and forwarding equipment in conifer stands. From the recorded references a large number of studies are in thinning followed by clear cut and final felling. The thinned stand's had the same tree diameter from 11.8 to $21.8 \mathrm{~cm}$. Due to this fact productivity values are similar having an average of $10 \mathrm{~m}^{3} / \mathrm{h}$. Different harvesting methods like conventional feeling and tossing the caber have a productivity difference of only $1.3 \mathrm{~m}^{3} / \mathrm{h}$. Only one topic was researched in a willow plantation showing the superior productivity and decreased cost of a harvester in relation to a harwarder system.

Tab. 5 Main findings of the cited literature in relation to productivity, cost and time consumption

\begin{tabular}{|c|c|c|c|c|}
\hline \multicolumn{5}{|c|}{ North America } \\
\hline References & $\begin{array}{l}\text { Tree } \\
\text { type }\end{array}$ & $\begin{array}{l}\text { Type of } \\
\text { cut }\end{array}$ & Stand characteristics & Major results \\
\hline $\begin{array}{l}\text { Lambert et al. } \\
\quad(1990)\end{array}$ & - & $\mathrm{CC}$ & Sl $27.5 \%$ & P 455 green tons/day. C 7.8\$/ton \\
\hline $\begin{array}{l}\text { Kellogg et al. } \\
(1994)\end{array}$ & Co & $\mathrm{T}$ & $\begin{array}{c}\text { D } 25.9 / 26.9 \mathrm{~cm} . \text { Avt } \\
0.09 \mathrm{~m}^{3}\end{array}$ & $\begin{array}{c}\text { Hr C } 4.46 \$ / \mathrm{m}^{3} . \text { F P } 15.3 \mathrm{~m}^{3} \text {, Di } 267 \mathrm{~m} . \text { Mixed } \\
\text { load technique C } 6.8 \$ / \mathrm{m}^{3}\end{array}$ \\
\hline $\begin{array}{l}\text { Richardson et al. } \\
\text { (1995) }\end{array}$ & - & $\mathrm{S}, \mathrm{T}$ & 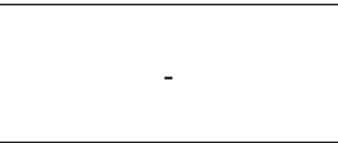 & $\begin{array}{c}\text { Hr P } 46 \text { to } 58 \text { trees } \mathrm{H} 0 \text { in } \mathrm{S} \text { and } 39 \text { to } 55 \\
\text { trees/Ho in T. C are } 10.18 \$ / \mathrm{m}^{3} \text { in } \mathrm{T} \text { and } \\
18.84 \$ / \mathrm{m}^{3} \text { in } \mathrm{S}\end{array}$ \\
\hline Tufts (1997) & - & PW,SL & - & $\begin{array}{c}\text { Hr P } 29.2 \mathrm{~m}^{3} \text { for PW and } 33.8 \mathrm{~m}^{3} \text { for SL/Ho. F } \\
\text { P } 34.6 \mathrm{~m}^{3} / \text { Ho and C of } 53 \$ / \mathrm{m}^{3} / \mathrm{H} \text {. }\end{array}$ \\
\hline $\begin{array}{l}\text { Huyler et al. } \\
\text { (1999) }\end{array}$ & M & CW,PW & $\begin{array}{l}\text { D } 20 \mathrm{~cm} \\
\text { Atv } 1.87 \mathrm{~m}^{3}\end{array}$ & $\begin{array}{c}\mathrm{H} 14.8 \mathrm{~m}^{3} \text { or } 47.48 \text { trees } \\
\text { Avg. time for travel, } \mathrm{Cu}, \text { De } 1.29 \mathrm{~min} .\end{array}$ \\
\hline Bulley(1999) & - & - & - & $\begin{array}{l}\text { Effect of Avt and stand density influence H } \\
\text { and F P, C for slash loading and tree damage. }\end{array}$ \\
\hline Meek (1999) & Co & $\mathrm{T}$ & - & Factors affecting the P in Co Tstands. \\
\hline Ewing (2001) & M & $\mathrm{T}$ & - & $\begin{array}{l}\mathrm{Hr} C 7-33 \$ / \mathrm{m}^{3} . \text { Fr C } 4-14 \$ / \mathrm{m}^{3} \\
\text { Experienced drivers low cost. }\end{array}$ \\
\hline Drewset al.(2001) & Co & - & D $12 \mathrm{~cm}, \mathrm{Sl} 12 \%$ & $\begin{array}{c}\text { F vs. YC is } 7 \$ \text { vs. } 33 \$ / \text { ton, F vs. Y P is } 12 \mathrm{~T} / \mathrm{SH} \\
\text { vs. } 9 \mathrm{~T} / \mathrm{SH} \text {. Stump to mill F vs. YC are } 46 \$ / \mathrm{Gt} \\
\text { vs. } 80 \$ / \mathrm{Gt}\end{array}$ \\
\hline Douglas (2004) & Co & $\mathrm{T}$ & $\begin{array}{c}\text { D } 24 \mathrm{~cm}, \text { Atv } 0.28 \\
\mathrm{~m}^{3}, \mathrm{Sl} 14 \% \\
\end{array}$ & H P was $19.17 \mathrm{~m} 3 /$ Ho while C are $5.54 \$ / \mathrm{m}^{3}$ \\
\hline $\begin{array}{l}\text { Grebneret al. } \\
\qquad(2005)\end{array}$ & - & - & - & $\begin{array}{l}\text { Routechasser program assess the vehicle } \\
\text { operating parameters, cost from stump to } \\
\text { mill transport }\end{array}$ \\
\hline Adebayo (2006) & - & $\begin{array}{l}\text { WT/ } \\
\text { CTL }\end{array}$ & $\begin{array}{l}\text { D } 27.5 \mathrm{~cm}, \mathrm{Sl} 18 \% \\
\text { Atv } 0.53 \mathrm{~m} 3\end{array}$ & $\mathrm{P}$ and $\mathrm{C}$ between the two harvesting methods \\
\hline
\end{tabular}


Tab. 5 (continued) Main findings of the cited literature in relation to productivity, cost and time consumption

\begin{tabular}{|c|c|c|c|c|}
\hline \multicolumn{5}{|c|}{ South America } \\
\hline $\begin{array}{l}\text { Linhareset al. } \\
\quad \text { (2012) }\end{array}$ & - & - & - & $\begin{array}{c}\text { H worked } 480 \text { h } 18 \text { min. } 75.6 \% \text { was effective } \\
\text { work while } 24.4 \% \text { downtime. F worked } 481 \\
\text { h } 36 \text { min were effective work was } 84.7 \% \text { and } \\
15.3 \% \text { downtime }\end{array}$ \\
\hline \multicolumn{5}{|c|}{ Nordic countries } \\
\hline $\begin{array}{l}\text { Gullberg } \\
\text { (1997) }\end{array}$ & - & - & - & $\begin{array}{l}\text { L time is related to pile characteristics, } \mathrm{L} \\
\text { conditions and operator }\end{array}$ \\
\hline $\begin{array}{l}\text { Glade } \\
(1999)\end{array}$ & & $S$ & D 32 to $38 \mathrm{~cm}$ & $\begin{array}{c}\text { P between SGH/DGH. C } 2.7-5.7 \$ \text { for SGH and } \\
3.3-6 \$ \text { for DGH }\end{array}$ \\
\hline $\begin{array}{l}\text { Glode et al. } \\
\quad(2001)\end{array}$ & - & $\begin{array}{c}\mathrm{CFF} / \\
\mathrm{TC}\end{array}$ & D $20 \mathrm{~cm}$, Avt $27.4 \mathrm{~m}^{3}$ & CFF $27.4 \mathrm{~m}^{3} / \mathrm{E}_{15}$, TC $26.1 \mathrm{~m}^{3} / \mathrm{E}_{15}$ \\
\hline $\begin{array}{l}\text { Westeret al. } \\
\quad(2003)\end{array}$ & Co & $\mathrm{T}$ & $\begin{array}{c}\text { D } 11.8-19.9 \mathrm{~cm}, \text { Avt } \\
0.18-0.26 \mathrm{~m}^{3}\end{array}$ & $\begin{array}{l}\text { P for final } \mathrm{T} \text { is } 10.9 \mathrm{~m}^{3} \text { for rotable load carrier } \\
\text { and } 10.3 \mathrm{~m}^{3} \text { for fixed carrier. For T P is } 6 \text { and } \\
5 \mathrm{~m}^{3} / \mathrm{E} .70 \%-80 \% \text { used for L and Hr. }\end{array}$ \\
\hline $\begin{array}{l}\text { Siren et al. } \\
\quad(2003)\end{array}$ & Co & $\mathrm{T} / \mathrm{RC}$ & Fr Di is $250 \mathrm{~m}$ & $\begin{array}{l}\mathrm{P} \text { for } \mathrm{H}-\mathrm{F} \text { is } 3.81 \mathrm{~m}^{3} / \mathrm{E}_{15} \text { for } 1^{\text {st }} \mathrm{T} \text { and } 7.87 \mathrm{~m}^{3} \\
/ \mathrm{E}_{15} \text { in RC.For } \mathrm{H} \text { an avg. } \mathrm{P} \text { is } 6.92 \mathrm{~m}^{3} / \mathrm{E}_{15} \text { in } 1^{\text {st }} \\
\mathrm{T} \text { and } 16.18 \mathrm{~m}^{3} / \mathrm{E}_{15} \text { in CF. }\end{array}$ \\
\hline $\begin{array}{l}\text { Andersson et al. } \\
\quad(2004)\end{array}$ & Co & $\mathrm{T}$ & $\begin{array}{c}\text { D } 12.5-20.7 \mathrm{~cm} \\
\text { Atv } 0.09-0.25 \mathrm{~m}^{3} \\
0 \% \mathrm{Sl} \\
\end{array}$ & $\begin{array}{l}\text { Strip road cut backwards } 12.1 \mathrm{~m}^{3} / \mathrm{E}_{0 .} \\
\text { Along the edge cut } 13 \mathrm{~m}^{3} / \mathrm{E}_{0} \\
\text { Both sides tree cutting } 11.9 \mathrm{~m}^{3} / \mathrm{E}_{0 .}\end{array}$ \\
\hline $\begin{array}{l}\text { Karha et al. } \\
\quad(2004)\end{array}$ & Co & $\mathrm{T}$ & - & $\begin{array}{c}1^{\text {st }} \mathrm{T} \text { P } 5.6-10.3 \mathrm{~m}^{3} / \mathrm{E} 15,2^{\text {nd }} \mathrm{T} \text { P } 9.1-12.7 \mathrm{~m}^{3} / \\
\mathrm{E}_{15} \text { C ( (small machines) } 7.5-14.2 \$ \text { and } 5.7- \\
10.5 \$ \text { (large ones). Operator skills influenced } \\
\text { the P up to } 40 \% \text {. }\end{array}$ \\
\hline $\begin{array}{l}\text { Nurminen et al } \\
\quad(2006)\end{array}$ & Co & CF,ST,T & $\begin{array}{l}\text { D } 14-33 \mathrm{~cm} \text {, Avt } 0.2- \\
0.9 \mathrm{~m}^{3}\end{array}$ & $\begin{array}{c}\text { Stem increase from } 0.4 \text { to } 0.6 \mathrm{~m}^{3} \text { then } \mathrm{P} \\
\text { increase is in avg. } 30 \% \text {. New assortments } \\
\text { decreses P to } 1.5-4 \% \text {. Increased loads } \\
\text { increases P. }\end{array}$ \\
\hline Woll et al. (2009) & Co & $\mathrm{T}$ & D 15.9 and $21.8 \mathrm{~cm}$ & $\mathrm{P}$ is $1.1 \mathrm{~m}^{3} / \mathrm{h}$ in $58 \mathrm{~h}$ and $\mathrm{P}$ is $4.7 \mathrm{~m}^{3} / \mathrm{h}$ in $29 \mathrm{~h}$ \\
\hline $\begin{array}{l}\text { Lars et al. } \\
\text { (2011) }\end{array}$ & & $\begin{array}{l}\text { dry/ } \\
\text { fresh } \\
\text { LR } \\
\end{array}$ & & $\begin{array}{c}\text { Fresh load was } 7.1 \mathrm{~T} \text { respectively } 6.7 \mathrm{~T} \text { when } \\
\text { dried. UL time } 509.8 \text { min dried, respectively } \\
508.1 \text { min fresh. No major differences. }\end{array}$ \\
\hline $\begin{array}{l}\text { Fulvio et al. } \\
\quad(2012)\end{array}$ & SW & $\mathrm{W}$ & - & $\begin{array}{l}\mathrm{H}-\mathrm{F} \text { P is } 2.30 \mathrm{DT} / \mathrm{Ho} \text { as for the HW } 0.9 \mathrm{ODT} / \\
\text { Ho. Op C } 20 \mathrm{E} / \mathrm{WH} \text {. Op H C are } 85.2 \mathrm{E} / \mathrm{WH} \text {, } \\
\text { 70.4E/WH for F and 79.6E/WH H.C for HW } \\
\text { are } 43 \% \text { more than for H-F. }\end{array}$ \\
\hline $\begin{array}{l}\text { Lindroos et al. } \\
\qquad \text { (2012) }\end{array}$ & - & $\mathrm{FF}$ & Fr Di $300 \mathrm{~m}$ to $500 \mathrm{~m}$ & $\begin{array}{l}\text { A trailer after } F \text { increased time and fuel } \\
\text { consumption during transport but resulted in } \\
\text { a reduction of fuel and time per Fr T }\end{array}$ \\
\hline $\begin{array}{l}\text { Mizaras et al. } \\
\quad(2008)\end{array}$ & - & SSC & $\begin{array}{l}0.1 \text { to } 1.0 \mathrm{~m}^{3} \\
0.1 \text { to } 0.5 \mathrm{~m}^{3}\end{array}$ & $\begin{array}{l}\mathrm{H} \mathrm{P} \text { and } \mathrm{HW} \text { is between } 10.7-46.5 \mathrm{~m}^{3} . \mathrm{C} \\
\text { ranges from } 1.7-8 \mathrm{E} / \mathrm{m}^{3} \text { to } 3.5-12.4 \mathrm{~m}^{3}\end{array}$ \\
\hline \multicolumn{5}{|c|}{ Oceania } \\
\hline $\begin{array}{l}\text { Evanson et al. } \\
\quad \text { (1996) }\end{array}$ & Co & - & $\begin{array}{c}\text { D } 45 \text { to } 52 \mathrm{~cm}, \text { Atv } \\
1.5 \text { to } 3 \mathrm{~m}^{3}\end{array}$ & $\begin{array}{l}\text { Processing head P in stockpile is } 77 \mathrm{~m}^{3} / \mathrm{H} \\
\text { with an avg. vol. of } 1.6 \mathrm{~m}^{3}, 77 \mathrm{~m}^{3} / \mathrm{H} \text { with an } \mathrm{Av} \\
\text { of } 3.1 \mathrm{~m}^{3} \text { in } \mathrm{Y}, 100 \mathrm{~m}^{3} / \mathrm{Ho} \mathrm{Av} \text { of } 1.95 \mathrm{~m}^{3} \text { for } \mathrm{Hr} \\
\text { and } 143 \mathrm{~m}^{3} / \mathrm{Ho} \text { for De and bunching. }\end{array}$ \\
\hline
\end{tabular}


Tab. 5 (continued) Main findings of the cited literature in relation to productivity, cost and time consumption

\begin{tabular}{|c|c|c|c|c|}
\hline $\begin{array}{l}\text { Nichoolls et al. } \\
\quad \text { (2004) }\end{array}$ & - & - & - & $\begin{array}{l}\text { Op fatigue in one/ two shiftwork operations was } \\
\text { observed. Rest breaks of } 10 \text { min. taken every } 90 \\
\text { min. contributes to increase P. }\end{array}$ \\
\hline Visser et al. (2011) & Co & - & $\begin{array}{l}\text { D } 39 \text { to } 45 \mathrm{~cm}, \text { Atv } 0.3 \\
\text { to } 5.2 \mathrm{~m}^{3} . \mathrm{D} 29 \text { to } 40 \\
\mathrm{~cm}, \text { Atv } 0.1 \mathrm{~m}^{3}-4.4 \mathrm{~m}^{3}\end{array}$ & $\begin{array}{l}\text { Time consumption was } 40 \% \text { for felling and } \\
\text { delimbing while the rest of } 60 \% \text { for bunching, } \\
\text { clearing, moving, delay. }\end{array}$ \\
\hline \multicolumn{5}{|c|}{ North-west and West of Europe } \\
\hline $\begin{array}{l}\text { Esteban et al. } \\
\qquad(2002)\end{array}$ & - & - & $\mathrm{t}-$ & $\begin{array}{l}\mathrm{P} \text { and } \mathrm{C} \text { equations. High differences between } \\
\text { small/large H. Tree/soil damage greater than the } \\
\text { foreign regulations. }\end{array}$ \\
\hline $\begin{array}{l}\text { Jirousek et al. } \\
\text { (2007) }\end{array}$ & - & $\mathrm{CF}$ & - & $\begin{array}{c}\text { H P between } 13.5 \text { to } 60.5 \mathrm{~m}^{3} / \mathrm{Ho} \text { and } \mathrm{H} \mathrm{C} \text { of } \\
\text { 105E/Ho. F C reached 68.5E/Ho }\end{array}$ \\
\hline \multicolumn{5}{|c|}{ Central Europe } \\
\hline Hoss et al. (1991) & - & $\mathrm{T}$ & $\begin{array}{l}\text { winter/summer } \\
\text { harvest }\end{array}$ & $\begin{array}{l}\text { Better } \mathrm{P} \text { in alternation of work between } \mathrm{H} \text { and } \\
\text { other related activities is recommended. }\end{array}$ \\
\hline Verani (2001) & SW & - & Fr Di is $700 \mathrm{~m}$ & $\begin{array}{c}\mathrm{L} \text { of poplar with a F was very long }(32.9 \% \text { of the } \\
\mathrm{L} \text { cycle). Avg. cycle was } 41.8 \mathrm{~min} \text { for an avg. load } \\
\text { of } 6.54 \mathrm{~T} \text { over } 700 \mathrm{~m}\end{array}$ \\
\hline $\begin{array}{l}\text { Stampfer et al. } \\
\quad(2001)\end{array}$ & M & - & $\begin{array}{l}\text { Sl of } 31 \text { to } 43 \% \text {. } \\
\text { Corridors from } 84 \text { to } \\
167 \mathrm{~m} \text {. Age } 55-100 \\
\end{array}$ & $\begin{array}{l}\text { Hr time for } 0.6 \mathrm{~m}^{3} \text { tree is one minute. Avg. } \\
\text { locomotion time is } 0.3 \mathrm{~min} / \mathrm{stop} \text {. Soil bearing } \\
\text { capacity is unfavorable }\end{array}$ \\
\hline $\begin{array}{l}\text { Ghaffarian et al. } \\
\qquad \text { (2007) }\end{array}$ & Co & - & $\begin{array}{c}\text { Sl } 11 \% \\
\text { Atv. } 0.31 \mathrm{~m}^{3} \text { to } 0.7 \mathrm{~m}^{3} \text {. }\end{array}$ & $\begin{array}{l}\text { Observed P was } 17.9 \mathrm{~m}^{3} / \text { productive scheduled } \\
\text { hour and the avg. load was } 10.04 \mathrm{~m}^{3} / \text { cycle. The } \\
\text { avg. costs were } 6.72 \mathrm{E} / \mathrm{m}^{3}\end{array}$ \\
\hline $\begin{array}{l}\text { Spinelli et al. } \\
\quad \text { (2008) }\end{array}$ & - & - & - & $\begin{array}{l}\text { Delays avg. } 28.9 \% \text { of the total schedule time from } \\
34 \text { studies, comprising } 7.1 \% \text { mechanical, } 4.7 \% \text { Op } \\
\text { and } 17.1 \% \text { other delays. }\end{array}$ \\
\hline $\begin{array}{l}\text { Holzleitner et al. } \\
\qquad(2010)\end{array}$ & - & - & - & $\begin{array}{c}\text { F have the largest } \mathrm{P} \text { h/year from Fr machines of } \\
\text { 2068/ Ho15, fuel consumption of } 11.1 \mathrm{l} / \mathrm{h} \text { and } \\
\text { repair costs of } 11.8 \mathrm{E} / \mathrm{h}\end{array}$ \\
\hline $\begin{array}{l}\text { Zimbalatti et } \\
\text { al(2010) }\end{array}$ & $\mathrm{B}$ & - & $\begin{array}{l}\text { S } 25 \% \text {, Fr Di } 1084 \mathrm{~m} \\
\text { Atv } 1 \text { to } 1.54 \mathrm{~m}^{3} \\
\end{array}$ & $\begin{array}{l}\text { Avg. Fr time is } 37 \text { min for a } 8.6 \mathrm{~m}^{3} \text { load. Avg. P } \\
\text { without delays is } 14.41 \mathrm{~m}^{3} \text { to } 15.11 \mathrm{~m}^{3}\end{array}$ \\
\hline $\begin{array}{l}\text { Purfuerst et al. } \\
\quad \text { (2011) }\end{array}$ & Co & $\mathrm{T}$ & Atv 0.09 to $0.22 \mathrm{~m}^{3}$ & $\begin{array}{l}12 \mathrm{H} \mathrm{Op} \text { and their long term output wee } \\
\text { observed. Avg. P. was } 7 \text { to } 16 \mathrm{~m}^{3} / \mathrm{Ho}_{15}\end{array}$ \\
\hline $\begin{array}{l}\text { Spinelli et al. } \\
\quad \text { (2011) }\end{array}$ & - & - & $\begin{array}{l}\text { Avg. tree volume is } \\
0.010 \text { to } 7 \mathrm{~m}^{3} \text { with an } \\
\text { avg. of } 0.346 \mathrm{~m}^{3}\end{array}$ & $\begin{array}{c}\text { General P model after } 38 \text { studies in which } 5239 \\
\mathrm{~m}^{3} \text { and } 329 \text { delay free hours were analyzed. Avg. } \\
\text { P is } 15.9 \mathrm{~m}^{3} / \text { delay free hour or } 46 \text { trees. }\end{array}$ \\
\hline Cacot et al. (2012) & - & $\mathrm{T}, \mathrm{CF}, \mathrm{OC}$ & - & $\begin{array}{c}\text { From French data base the } \mathrm{H} \text { worked during } \\
2010 \text { and } 2011 \text { in } 125 \mathrm{~T} \text { sites, } 126 \mathrm{CC} \text { while the F } \\
\text { worked in } 67 \mathrm{~T} \text { and } 52 \text { clear cut stands }\end{array}$ \\
\hline \multicolumn{5}{|c|}{ Balkan countries } \\
\hline $\begin{array}{l}\text { Stankic et al. } \\
\text { (2011) }\end{array}$ & - & - & - & $\begin{array}{l}\text { F P depends on the class, hauling Di, load } \\
\text { characteristics, terrain and stand conditions }\end{array}$ \\
\hline $\begin{array}{l}\text { Stankik et al. } \\
\quad(2012)\end{array}$ & - & - & - & $\begin{array}{l}\text { Analyzed the impact factors as a special aspect of } \\
\text { primary transport of wood }\end{array}$ \\
\hline \multicolumn{5}{|c|}{ East of Europe } \\
\hline Jodlowski (1999) & Co & $\mathrm{T}$ & - & $\begin{array}{l}\text { Hr C and damage were when chainsaw and F } \\
\text { were used. Harvester and forwarder showed the } \\
\text { higher costs. }\end{array}$ \\
\hline
\end{tabular}


Tab. 5 (continued) Main findings of the cited literature in relation to productivity, cost and time consumption

\begin{tabular}{|c|c|c|c|c|}
\hline Suwala (1999) & Co & $\mathrm{T}$ & - & $\begin{array}{l}\text { Smallest } \mathrm{C} \text { was for chainsaw and } \mathrm{F} \text { for hauling } \\
\text { distances of } 100 \mathrm{~m} \text { and } 30-40 \mathrm{~m} \text { between tracks. } \\
\text { The most efficient was the } \mathrm{H} \mathrm{F} \text { for dist. to } 100 \mathrm{~m} \text {. }\end{array}$ \\
\hline $\begin{array}{l}\text { Dvorak et al. } \\
\quad \text { (2006) }\end{array}$ & - & - & Sl 10\% - 20\% & $\begin{array}{l}\text { Optimum diameter for } \mathrm{H} \mathrm{P} \text { is } 0.3 \text { to } 0.35 \mathrm{~m}^{3} \text { while } \\
\text { on volumes more than } 0.45 \text { to } 0.5 \mathrm{~m}^{3} \text { the time } \\
\text { consumption goes up. F maximum performance } \\
\text { during the distance interval of } 200-400 \mathrm{~m} \text { and a } \\
\text { mean vol. of } 0.45-0.5 \mathrm{~m}^{3} \text {. }\end{array}$ \\
\hline Mederski (2011) & Co & $\mathrm{T}$ & $\begin{array}{c}\text { Stand age of } 44 \text { and } \\
72 \text { years old. }\end{array}$ & $\begin{array}{c}\mathrm{H} P \text { in } \mathrm{MF} \text { and } \mathrm{Sr} \text { in the } 44 \text { old stand is } 5.87 \mathrm{~m}^{3} \\
\text { respectively } 4.52 \mathrm{~m}^{3} \text { and for the F P was } 5.03 \\
\text { repectively } 4.52 \mathrm{~m}^{3} \text {. For the } 72 \text { year old stand the } \\
\mathrm{H} \text { P is } 11.53 \mathrm{in} \mathrm{MF} \text { and } 8.70 \mathrm{~m}^{3} \text { in SR while for the } \\
\text { F P. is } 11.22 \text { respectively } 8.84 \mathrm{~m}^{3} \text {. Fr C lower in MF } \\
\text { than SR. }\end{array}$ \\
\hline
\end{tabular}

Concluded that operator working experience is

Dvorak et al.

(2008) greater than the the education, differences in total of 64.95 second were found between two operators.

\begin{tabular}{|c|c|c|c|c|}
\hline $\begin{array}{l}\text { Macku et al. } \\
\quad(2010)\end{array}$ & Co & IF & $\begin{array}{l}\text { D } 26 \text { to } 30 \mathrm{~cm}, \mathrm{Atv} \\
0.67 \text { to } 0.91 \mathrm{~m}^{3}\end{array}$ & $\begin{array}{l}\text { They found out that incidental felling is not } \\
\text { lowering the efficiency of the harvester on a } 25 \% \\
\text { Sl ground. }\end{array}$ \\
\hline $\begin{array}{l}\text { Szewczyk et al. } \\
\text { (2010) }\end{array}$ & M & - & $\begin{array}{l}\text { D } 23.5 \mathrm{~cm} \\
\text { Atv } 0.4 \mathrm{~m}^{3}\end{array}$ & $\begin{array}{c}\text { The } \mathrm{H} \text { moves } 31 \% \text { of the working cycle and the } \\
\text { cutting time is } 45 \% \text {. C were } 3.97 \mathrm{E} / \mathrm{m}^{3} / 12 \mathrm{~h} \text { shift } \\
\text { and } 3.47 \mathrm{E} / \mathrm{m}^{3} / 16 \mathrm{~h} \text { shift. Chainsaw cost for } 8 \mathrm{~h} \\
\text { shift is } 4.02 \mathrm{E} / \mathrm{m}^{3} \text {. }\end{array}$ \\
\hline $\begin{array}{l}\text { Dvorak et al. } \\
\qquad(2011)\end{array}$ & - & - & Sl up to $33 \%$ & $\begin{array}{c}\text { F P is } 7.7 \text { to } 16.7 \mathrm{~m}^{3} / \mathrm{h} \text { with an Av per load of } \\
33 \mathrm{~m}^{3} \text {. Ratio of work operations driving empty } \\
15 \% \text {, L time } 43 \% \text {, driving loaded } 15 \% \text { and UL } \\
\text { time is } 26 \% \text {.Normal shift time consumption is } \\
76 \% \text { of the total shift time. }\end{array}$ \\
\hline $\begin{array}{l}\text { Mederski et al. } \\
\quad \text { (2011) }\end{array}$ & Co & $\mathrm{T}$ & 55 year old pine & $\begin{array}{l}\text { T intensity varied from } 43.52 \text { to } 98.12 \mathrm{~m}^{3} / \mathrm{ha} \text {. An } \\
\text { avg. T intensity of } 57.56 \text { to } 75.56 \mathrm{~m}^{3} / \mathrm{ha} \mathrm{resulted} \text { res. } 23.14 \text { to } 28.08 \mathrm{~m}^{3} / \mathrm{ha} \\
\text { in } 21 \% \text { better L P from }\end{array}$ \\
\hline $\begin{array}{l}\text { Brzozko et al. } \\
\quad \text { (2012) }\end{array}$ & Co & $\mathrm{WF}$ & $\begin{array}{l}\text { Avg. vol. of } 0.1 \text { to } \\
1.4 \mathrm{~m}^{3}\end{array}$ & $\begin{array}{l}\text { The productivity of an experienced operator } \\
\text { ranges from } 7 \text { to } 68 \text { sec. while for the } \\
\text { inexperienced one is } 11 \text { to } 177 \text { seconds }\end{array}$ \\
\hline $\begin{array}{l}\text { Gerasimov et al. } \\
\text { (2012) }\end{array}$ & M & $\mathrm{CF}$ & $\begin{array}{l}\text { Avg. stem volume is } \\
0.31 \mathrm{~m}^{3} / \text { under bark }\end{array}$ & $\begin{array}{l}\text { The harvester produced from } 4.3 \text { to } 14.9 \mathrm{~m}^{3} \mathrm{u} . \mathrm{b} / \mathrm{Ho} \\
\text { and } 16 \text { to } 49.5 \mathrm{~m}^{3} \mathrm{u} . \mathrm{b} / \text { stem processing machine } \\
\text { hour. Time processing varied from } 0.17 \text { to } 0.45\end{array}$ \\
\hline
\end{tabular}

For Oceania the tree diameter had increased showing harvesting productivities of $143 \mathrm{~m}^{3} /$ productive working hour. Another study was revealing $40 \%$ time consumption for felling and delimbing while the rest is for bunching, clearing, moving and delays.
For the rest of Europe the data was obtained mostly in thinned stands with average tree volumes ranging from 0.09 to $0.9 \mathrm{~m}^{3}$. Productivity was in average from 5 to $15 \mathrm{~m}^{3} / \mathrm{h}$ for the harvester. 


\section{Analysis of the fuel, lubricants and spare part consumption}

Consumption of fuel, lubricants and spare parts is an important factor which is influencing also the stump to mill wood price. An improper use of the technologies will have negative consequences on the economical side of the wood chain but also a great impact on the environment. From the five studies four of them are realized in the Nordic countries and one is developed in Continental Europe. A bench mark for reporting consumption is at the round value of $1000 \mathrm{~m}^{3}$. Air pollution as well as soil has a great impact on the topics.

\section{Analysis of soil and tree damage}

Second largest section is analyzing the short and long term impact on trees and soil. Most of the samples were taken at depths from 0 to 30 $\mathrm{cm}$ to evaluate the compaction degree of the soil. Tire pressure and with is not so important as the number of passes and load of the machines. After

Tab. 6 Main findings of the cited references in relation to fuel, lubricants and spare parts consumption

\begin{tabular}{|c|c|c|c|c|}
\hline Authors & $\begin{array}{l}\text { Tree } \\
\text { type }\end{array}$ & $\begin{array}{l}\text { Type } \\
\text { of cut }\end{array}$ & $\begin{array}{c}\text { Stand } \\
\text { characteristics }\end{array}$ & Major results \\
\hline $\begin{array}{l}\text { Athanassiadis et } \\
\text { al. (1996) }\end{array}$ & - & $\mathrm{t}-$ & - & $\begin{array}{l}\text { Consumption for } 1000 \mathrm{~m}^{3} \mathrm{u} . \mathrm{b} \text { was } 935 \mathrm{l} \text { diesel for } \mathrm{F} \text { and } \\
\text { an avg. of } 1088.5 \mathrm{l} \text { for the } \mathrm{H} \text {, hydraulic oil was } 17 \mathrm{l} \text { forF } \\
\text { and } 33.6 \mathrm{l} \text { forH, chainsaw oil } 2.8 \mathrm{l} \text {. Spills were } 20 \mathrm{l} \text { for } \\
\text { hydraulic oil and } 35 \mathrm{l} \text { for chainsaw oil. }\end{array}$ \\
\hline $\begin{array}{l}\text { Nordfjell et al. } \\
\quad \text { (2003) }\end{array}$ & Co & $\begin{array}{l}\text { SL/ } \\
\text { PW }\end{array}$ & $\begin{array}{l}\text { Atv0.22 } \mathrm{m}^{3} \\
\text { Fr Di } 360 \text { to } \\
514 \mathrm{~m}\end{array}$ & $\begin{array}{l}\text { The consumption was with } 53-83 \% \text { higher for PW } \\
\text { than SL. The P was with } 37 \text { to } 50 \% \text { lower for PW. Field } \\
\text { consumption was } 8.3 \text { to } 15.71 / \text { Ho. }\end{array}$ \\
\hline $\begin{array}{l}\text { Nordfjell et al. } \\
\quad \text { (2007) }\end{array}$ & - & - & - & $\begin{array}{c}\text { Lubrication characteristics of } 2 \text { vegetable and } 1 \text { mineral } \\
\text { oil in laboratory. The study revealed that a oil flow } \\
\text { of } 2 \mathrm{ml} / \mathrm{min} \text { was found to be enough to prevent high } \\
\text { temperature on all oil types. }\end{array}$ \\
\hline $\begin{array}{l}\text { Klavac et al. } \\
\text { (2009) }\end{array}$ & - & $\mathrm{CF}$ & - & $\begin{array}{c}\text { Co2 values was } 9.63 \mathrm{~kg} / \mathrm{m}^{3} \text { of delivered timber for diesel } \\
\text { and } 10.64 \mathrm{~kg} / \mathrm{m}^{3} \text { for rapesee methyl ester. }\end{array}$ \\
\hline $\begin{array}{l}\text { Athanassiadis et } \\
\text { al. (2000) }\end{array}$ & - & - & - & $\begin{array}{c}\text { LCA analysis for } 1000 \mathrm{~m}^{3} \text { of } \mathrm{Hr} \text { and Fr wood. } 1321 \\
\text { spare parts were included in this study. Min. } 46 \mathrm{~kg} \text { of } \\
\text { spare parts and a max. of } 58 \mathrm{~kg} \text { are used for this wood } \\
\text { amount. On the life cycle of the machine about } 38-45 \% \\
\text { of the total mass will be replaced. }\end{array}$ \\
\hline
\end{tabular}

Tab. 7 Main findings to the cited literature in relation to tree and soil damage

\begin{tabular}{|c|c|c|}
\hline \multicolumn{3}{|r|}{ North America } \\
\hline Authors & $\begin{array}{l}\text { Forest } \\
\text { type }\end{array}$ & Major results/ Research topic \\
\hline $\begin{array}{l}\text { McNeal et } \\
\text { al.(1992) }\end{array}$ & Co & $\begin{array}{l}\text { Studied } 106 \text { plots to find out that the tree damage is in avg. } 40 \mathrm{~cm}^{2}, 20 \% \text { of the } \\
\text { surface is occupied by tracks, and } 13 \% \text { presents soil damage }\end{array}$ \\
\hline $\begin{array}{l}\text { Landsber et al. } \\
\text { (2003) }\end{array}$ & M & $\begin{array}{l}\text { Compaction was in the legal limits, on steep terrain the effect was less than on } \\
\text { flat terrain }\end{array}$ \\
\hline $\begin{array}{l}\text { Sutherland } \\
\text { (2003) }\end{array}$ & - & $\begin{array}{l}\text { For limiting the negative effects of Hr by using tracked machines for low } \\
\text { pressure on the soil, lowering the F payload, moving to drier frozen areas }\end{array}$ \\
\hline Froese (2004) & Co & $\begin{array}{l}\text { From } 18.8 \mathrm{ha}, 38.3 \% \text { was moderate disturbed. Compaction was measured at } 10- \\
20-30 \mathrm{~cm} \text {. Soil resistance for penetration grew with } 13.8 \% \text { after F pass. }\end{array}$ \\
\hline Han et al.(2006) & Co & $\begin{array}{l}\text { Samples taken at } 10-20-30 \mathrm{~cm} \text {. Results at } 10 \text { and } 20 \mathrm{~cm} \text { showed higher } \\
\text { compaction but at } 30 \mathrm{~cm} \text { the penetration resistance was not significantly. }\end{array}$ \\
\hline
\end{tabular}


Tab. 7 (continued) Main findings to the cited literature in relation to tree and soil damage

\begin{tabular}{|c|c|c|}
\hline Han S.,K., (2006) & Co & $\begin{array}{l}\text { At the same humidity in soil both CTL and WT method produced the same } \\
\text { compaction values. Heavy slash is reducing soil compaction on corridors. }\end{array}$ \\
\hline $\begin{array}{l}\text { Labelle et al. } \\
\qquad(2011)\end{array}$ & $\mathrm{M}$ & $\begin{array}{c}\text { Measured the compaction after } 5 \text { years from the Hr time. Soil density grew from } \\
\text { with } 15.5 \% \text { respectively } 17.5 \% \text { after Hr. Compaction was present even at } 1 \text { meter } \\
\text { aside the tracks. After } 5 \text { years the soil had not fully recovered. }\end{array}$ \\
\hline \multicolumn{3}{|r|}{ South America } \\
\hline $\begin{array}{l}\text { Lineros et al. } \\
\text { (2003) }\end{array}$ & Co & $\begin{array}{l}20 \text { m circular plots were used to assess the tree damage, only } 12.3 \% \text { of the } 16 \\
\text { year old pine trees had some kind of damage }\end{array}$ \\
\hline Dias et al. (2007) & $\mathrm{B}$ & $\begin{array}{l}27 \text { soil samples were taken before and after harvesting. After } 8 \text { years the soil } \\
\text { had recovered after the harvesting process with harvester, forwarder and feller- } \\
\text { buncher. }\end{array}$ \\
\hline \multicolumn{3}{|r|}{ Oceania } \\
\hline $\begin{array}{l}\text { Wood et al. } \\
\qquad(2006)\end{array}$ & - & $\begin{array}{l}\text { Cone penetrations resistances were linear with depth, to approx. } 20 \mathrm{~cm} \text {. Below } \\
\text { that they are relatively constant. Penetration resistances increased with nr. of } \\
\text { passes in dry season, in wet season the pattern was not evident. }\end{array}$ \\
\hline \multicolumn{3}{|r|}{ North-West of Europe } \\
\hline $\begin{array}{l}\text { Nugent et al. } \\
(2003)\end{array}$ & - & $\begin{array}{l}\text { Erosion after harvester passes was } 10.2 \times 10^{-2} \mathrm{~cm} / \mathrm{m} \text {, and varied between } 0.7 \text { and } \\
\qquad 24.7 \times 10^{-2} \mathrm{~cm} / \mathrm{m}\end{array}$ \\
\hline $\begin{array}{l}\text { Wood et al. } \\
\text { (2003) }\end{array}$ & Co & $\begin{array}{l}\text { Where terrain and slash road design are non-limiting, slash road have the } \\
\text { potential to provide sustained ground protection. }\end{array}$ \\
\hline \multicolumn{3}{|r|}{ Asia } \\
\hline $\begin{array}{l}\text { Matangaran } \\
\quad(2012)\end{array}$ & $\mathrm{B}$ & $\begin{array}{c}\text { Measurement were take up to } 50 \mathrm{~cm} \text { in depth and soil humidity of } 23 \% \text {. At one } \\
\text { pass compaction was } 32.22 \% \text { more (no branches on the track) and } 10 \% \text { when } \\
\text { branches were on the track }\end{array}$ \\
\hline \multicolumn{3}{|r|}{ Nordic countries } \\
\hline Siren (2001) & Co & $\begin{array}{l}65 \% \text { of the tree damage was made by the falling trees. An avg. of } 54 \mathrm{~cm}^{2} \text { was } \\
\text { for light injuries and } 81 \mathrm{~cm}^{2} \text { was for severe injuries. } 92.4 \% \text { of the damages was } \\
\text { observed on the stem and } 7.6 \% \text { was at the roots. The damages for the summer } \\
\text { operation was double }\left(78 \mathrm{~cm}^{2}\right) \text { than in winter operations }\left(39 \mathrm{~cm}^{2}\right)\end{array}$ \\
\hline $\begin{array}{l}\text { Granhus et al. } \\
\quad(2001)\end{array}$ & Co & $\begin{array}{l}\text { Studied the injury and mortality in } 24 \times 28 \mathrm{~m} \text { plots. Morality varied from } 5 \text { to } 51 \% \\
\text { while the injury varied from } 17 \text { to } 76 \%\end{array}$ \\
\hline Eliasson (2005) & Co & $\begin{array}{l}\text { At tire pressure of 300-450-600 kPa the only factor that affects compaction is the } \\
\text { number of passes. Harvester increased the soil density until depths of } 30 \mathrm{~cm}\end{array}$ \\
\hline $\begin{array}{l}\text { Eliasson et al. } \\
\quad(2007)\end{array}$ & - & $\begin{array}{l}\text { Studied the effect of } 0-10-20 \mathrm{~cm} \text { of slash on soil compaction. Slash roads are } \\
\text { reducing compaction on the first } 20 \mathrm{~cm} \text { of soil. One pass on } 0 \mathrm{~cm} \text { slash road } \\
\text { equals with } 5 \text { passes on slash road regarding soil compaction }\end{array}$ \\
\hline $\begin{array}{l}\text { Sakai et al. } \\
\qquad \text { (2008) }\end{array}$ & Co & $\begin{array}{c}\text { They studied compaction degree after } 1,8 \text { and } 24 \text { passes at a soil humidity of } \\
60 \% \text {. After } 8 \text { passes the compaction degree was high. High tire pressure results } \\
\text { in deep soil compaction }\end{array}$ \\
\hline $\begin{array}{l}\text { Lindroos et al. } \\
\qquad \text { (2011) }\end{array}$ & - & $\begin{array}{c}\text { For distances more than } 200 \mathrm{~m} \text { a forwarder }+ \text { trailer showed the efficiency on } \\
\text { larges loads with decreased damage.Also the cost are decreasing when using a } \\
\text { cheap trailer after the forwarder }\end{array}$ \\
\hline \multicolumn{3}{|r|}{ Central Europe } \\
\hline $\begin{array}{l}\text { Wilpert et al. } \\
\quad(1992)\end{array}$ & Co & $\begin{array}{l}\text { Because using small class machines only } 5 \% \text { of the surface is damaged. In the } \\
\text { future they predicted that } 10 \% \text { of the surface will be affected }\end{array}$ \\
\hline
\end{tabular}


Tab. 7 (continued) Main findings to the cited literature in relation to tree and soil damage

\begin{tabular}{|c|c|c|}
\hline $\begin{array}{l}\text { Matthies et al. } \\
\quad(1995)\end{array}$ & & $\begin{array}{l}\text { Revealed than a tire pressure of less than } 500 \mathrm{kPa} \text { will not affect the soil, it's } \\
\text { functions will recover in time }\end{array}$ \\
\hline Weise (2002) & - & $\begin{array}{l}\text { Quantified the impact of heavy machinery (harvester, forwarder, skidder) on soil } \\
\text { compaction in relation to tire pressure, load, type of tire }\end{array}$ \\
\hline $\begin{array}{l}\text { Limbeck-Lilienau } \\
\qquad(2003)\end{array}$ & - & $\begin{array}{l}\text { The harvester forwarder system caused in winter } 3 \% \text { to } 6 \% \text { tree damage while } \\
\text { in summer } 12 \text { to } 15 \% \text { damage. The system forwarder cable yarder had } 20 \text { to } \\
40 \% \text { tree damage }\end{array}$ \\
\hline $\begin{array}{l}\text { Cacot et al. } \\
(2006)\end{array}$ & - & $\begin{array}{l}\text { Analyzed the soil impact of harvester with various tires and pressure during } \\
1999-2002\end{array}$ \\
\hline $\begin{array}{l}\text { Ampoorter et al. } \\
\quad \text { (2007) }\end{array}$ & - & $\begin{array}{l}\text { Harvester induced an increase of soil properties in the upper } 30 \mathrm{~cm} \text { of the } \\
\text { soil compared with undisturbed one. Sandy soils are expected to recover very } \\
\text { slowely. }\end{array}$ \\
\hline $\begin{array}{l}\text { Ampoorter et al. } \\
\quad(2012)\end{array}$ & - & $\begin{array}{l}\text { Literature review on impact on sandy and clayey forest soils during } 1955-2007 \\
\text { periods. In most of the cases compaction reach } 30 \mathrm{~cm} \text { in depth with the } 0-10 \mathrm{~cm} \\
\text { layer being the most affectedt. Number of passes varied from } 1 \text { to } 12\end{array}$ \\
\hline \multicolumn{3}{|r|}{ Balkan countries } \\
\hline $\begin{array}{r}\text { Porsinsk } \\
\quad(200\end{array}$ & B & $\begin{array}{r}\text { Used two methods to describe traf } \\
\text { penetration } \mathrm{r}\end{array}$ \\
\hline Mali (2007) & - & Studied the soil impact on the tracks used by the harvester and forwarder \\
\hline $\begin{array}{l}\text { Tsioras et al. } \\
\quad(2010)\end{array}$ & B & $\begin{array}{l}2 \mathrm{~m} \text { away from the skidding road trees were observed, showed that } 20 \% \text { of the } \\
\text { trees were damaged }\end{array}$ \\
\hline Zoric et al. (2012) & B & $\begin{array}{l}\text { Compaction due to forwarder passes (from } 4 \text { to } 13 \text { times) at a tested depth of } \\
0 \text { to } 15 \mathrm{~cm} \text {. On good bearing soil the effects are low. No correlation were found } \\
\text { between nr. of passes and compaction }\end{array}$ \\
\hline $\begin{array}{l}\text { Porsinski et al. } \\
\qquad \text { (2012) }\end{array}$ & - & $\begin{array}{l}\text { Using tracked wheeled is lowering the soil damage while using } 710 \mathrm{~mm} \text { tires is } \\
\text { not satisfactory with increased load compared to the } 600 \mathrm{~mm} \text { ones. Using } 4 \text { axes } \\
\text { machines lowers also the soil pressure }\end{array}$ \\
\hline \multicolumn{3}{|r|}{ Eastern Europe } \\
\hline $\begin{array}{l}\text { Moskalik et al. } \\
\quad \text { (1998) }\end{array}$ & - & $\begin{array}{l}\text { Studied compaction and tree damage degree of horses, forwarder, harvester and } \\
\text { skidders. The horse had the lowest compaction impact while the skidder had the } \\
\text { greatest. Most tree damage was made by the skidder, the lowest were made by } \\
\text { the forwarder }\end{array}$ \\
\hline Suwla (1999) & - & $\begin{array}{l}\text { Observed two harvesting methods. The first with chainsaw and horse } 2.8 \% \\
\text { damage in } 1^{\text {st }} \text { thinning and } 5.3 \% \text { in } 2^{\text {nd }} \text { thinning. For the chainsaw and forwarder } \\
\text { the damage was } 3.4 \% \text { in the first thinning respectively } 3.9 \% \text { in the } 2^{\text {nd }} \text { thinning }\end{array}$ \\
\hline Rosnovski (2001) & Co & $\begin{array}{l}\text { Determined the soil compaction degree on road with and without slash } \\
\text { reinforcements }\end{array}$ \\
\hline Gapsyte (2003) & Co & $\begin{array}{l}\text { In a pine stand aged } 35 \text { to } 98 \text { years old the tree damage was } 51 \% \text { of the total } \\
\text { tree number due to the working method. Lowest impact had the chainsaw and } \\
\text { forwarder method }\end{array}$ \\
\hline Dvorak (2006) & Co & $\begin{array}{l}\text { Damages were } 2 \text { to } 3.6 \% \text { from the observed spruce trees. In the } 3 \text { years class a } \\
\text { nr. } 19-23 \text { trees were damaged while in the } 5 \text { year age class a number of } 23-28 \\
\text { trees were damaged }\end{array}$ \\
\hline
\end{tabular}


Tab. 7 (continued) Main findings to the cited literature in relation to tree and soil damage

\begin{tabular}{ccc}
\hline $\begin{array}{c}\text { Gerasimov et al. } \\
(2010)\end{array}$ & - & $\begin{array}{c}\text { The track influence on soil compaction varied, bulk density increased with } 1.30 \mathrm{~g} / \\
\mathrm{cm}^{3} \mathrm{vs} .1 .24 \mathrm{~g} / \mathrm{cm}^{3} \text { on moist soils and it was the same on wet soilsby the } 10^{\text {th }} \text { pass. }\end{array}$ \\
\hline $\begin{array}{c}\text { Gebauer } \text { et al. } \\
(2010)\end{array}$ & - & $\begin{array}{c}\text { Demonstrated that the maximum soil compaction factor is exceeded due to the } \\
\text { heavy machinery. } \mathrm{Co}_{2} \text { level from soil and air raised after using the harvester and } \\
\text { forwarder system. }\end{array}$ \\
\hline $\begin{array}{c}\text { Rejšek } \text { et al. } \\
(2011)\end{array}$ & - & $\begin{array}{c}\text { Measurments were taken in the upper soil horizon to reveal the soil compaction } \\
\text { and impact. Measurements were repeated after } 6 \text { months. They showed that each } \\
\text { area is responding different to compaction and soil recovery }\end{array}$ \\
\hline $\begin{array}{c}\text { Gerasimov } \text { et al. } \\
(2012)\end{array}$ & - & $\begin{array}{c}\text { Found that the dame on industrial round wood is made by feed rolers and } \\
\text { delimbing knives. The rejection rate is low if the harvester head has sharp knives. }\end{array}$ \\
\hline
\end{tabular}

some authors the soil had fully recovered after 8 years had passed since the operation took place while after other after 5 years the soil had not recovered. Harvesting and forwarding operation during winter produces less damages then in summer, although soil impact due to the machines is varying from region to region.

\section{Computer simulations}

The last section refers to simulating the entire real work situation with the help of a computer. Soil compaction, productivity, different harvesting and forwarding systems operated with experienced and inexperienced operators are subject to the references.

\section{CONCLUSIONS}

Following this study, several conclusions may be drawn, especially in what concerns the forest type and topography specific to Romania. As shown by this literature review, the majority of the studies were made in coniferous stands were the forest equipment such as harvesters had normal working conditions, because such equipment was designed for such tree species. By considering that in Romania the percentage of coniferous species occupies $28 \%$ of the total forested area, deploying such equipment may lead to considerably increments of productivity, additionally serving to work safety. Nevertheless, forwarder equipment can be deployed also in broadleaved stands due to the fact that such equipment does not have

Tab. 8 Main findings of the cited references in relation to computer simulations

\begin{tabular}{|c|c|c|}
\hline Authors & $\begin{array}{l}\text { Forest } \\
\text { type }\end{array}$ & Major results/ Research topic \\
\hline $\begin{array}{l}\text { Wang et al. } \\
\qquad(1999)\end{array}$ & - & $\begin{array}{c}\text { Are doing simulations in order to raise efficiency while stand slope and damage } \\
\text { are not mentioned. Feling on a } 0.16 \text { ha stand took } 10 \text { to } 35 \text { min while skidding } \\
\text { took } 40 \text { to } 90 \text { min on a } 7.8 \text { ha stand. Both methods were influence by stand } \\
\text { density, machine factors }\end{array}$ \\
\hline $\begin{array}{l}\text { Nuutinen et al. } \\
\text { (2008) }\end{array}$ & - & $\begin{array}{l}\text { Made time studies via the simulator screen with experienced and inexperienced } \\
\text { operators. Inexperienced operators made more mistakes but statistically the } \\
\text { difference were not significant between groups }\end{array}$ \\
\hline Belbo (2010) & - & $\begin{array}{l}\text { Simulated harvester efficiency which increased rapidly when the grapple } \\
\text { diameter increased from } 2 \text { to } 4 \text { times the avg. diameter }\end{array}$ \\
\hline Jori et al. (2010) & - & Are simulating how many passes can a forwarder do on a low bearing soil \\
\hline $\begin{array}{l}\text { Lamminen et al. } \\
\qquad \text { (2011) }\end{array}$ & - & $\begin{array}{c}\text { Found out } 40 \text { to } 50 \% \text { differences on simulator between experienced and } \\
\text { inexperienced operators. They try to found out factors that influence prod. and } \\
\text { also loading phase. The speed and boom out of the crane is most important in } \\
\text { prodyctivity }\end{array}$ \\
\hline $\begin{array}{l}\text { Talbot et al. } \\
\qquad(2003)\end{array}$ & - & $\begin{array}{l}\text { Are comparing a harwarder with a harvetser forwarder system, both systems } \\
\text { show a competitive advantage, in forest structures with low object volumes or } \\
\text { frequent relocation }\end{array}$ \\
\hline
\end{tabular}


specific limitations related to the tree species, which otherwise is the case of harvesters. On the other hand, there were only few international studies analyzing the work productivity when harvesting timber having tree diameter over 40 $\mathrm{cm}$ and terrain slope over 30\%. Future analysis should be done also in this direction due to the fact that a large proportion of the Romanian forests are over 40 years old. Also, in the case of clear cuts or uniform selective cuts, harvesting volumes can range from $250 \mathrm{~m}^{3} /$ ha in case of a 40 year old stand, up to $400 \mathrm{~m} 3 /$ ha in case of a 100 year old stand. Indeed in case of harvesting small volumes these machines are not profitable due to the low productivities and high operating costs. Another aspect that should be taken in account is the lack of special made harvester and forwarder corridors that these machines require in order to achieve their productive capacity. Also, little is known about how the effective tree marking operations, like those conducted in Romania, could influence the work productivity when using such forest equipment. Operator training, therefore his or her experience in operating harvesters or forwarders is an important issue not only in Romania; such aspects should be studied especially since in Romania no purpose designed training programs are available.

Acknowledgment: This paper is supported by the Sectorial Operational Programme Human Resources, Development (SOP HRD), ID 134378 financed from the European Social Fund and by the Romanian Government.

\section{REFERENCES:}

1. Adebola BA (2006). Productivity And Cost Of Cut-ToLenght And Whole-Tree Harvesting In A Mixed-Conifer Stand. In: Master Thesis, University of Idaho.

2. Ampoorter E, Schrijver A, Nevel L, Hermy M, Verheyen K (2012). Impact of mechanized harvesting on compaction of sandy and clayey forest soils: results of a meta-analysis. Annals of Forest Science 69:533-542.

3. Ampoorter E, Goris R, Cornelis WM, Verheyen, K (2007). Impact of mechanized logging on compaction status of sandy forest soils.Forest Ecology and Management 241(1/3):162-174.

4. Andresson J,Eliasson, L (2004).Effects on three harvesting work methods on harwarder productivity in final felling. Silva Fennica 38(2):195-202.

5. Athanassiadis D, Wästerlund I, Lidestav G (1996). Fuel, Hydraulic Oil and Lubricant Consumption in Swedish
Mechanized Harvesting Operations. Int. Journal of Forest Engineering 29:59-66.

6. Athanassiadis D, Lidestav G, Wasterlund I (2000). Assesing material consumption due to spare part utilization by harvesters and forwarders.Jou. of Forest Eng. 11(2).

7. Belbo $H$ (2011). A simulation approach to determine the potential efficiency in multi tree felling and processing. Formec Austria.

8. Brzozko J, Zychowicz W, Bartosiewicz M (2012). The influence of operator experience on productivity on mechanised timber harvesting from windfall stands. Formec Croatia.

9. Bulley B (1999). Effect of tree size and stand density on harvester and forwarder productivity in commercial thinning.For. Eng. Res. Inst. of Canada 292:8.

10. Cacot E (2012). Online data base for harvester and forwarders productivities. Formec Croatia.

11. Cacot E, Pischedda D (2006). Forest utilization and soil conservation. Sherwood - Forest edAlberiOggi 126:25-30.

12. Dias Junior MS, Fonseca S, AraújoJúnior CF, Resende Silva A (2007). Soil compaction due to forest harvest operations.Pesq.agropec. bras. vol.42 no.2 Brasília.

13. Douglas RT (2004). Productivity of a Small Cut-to-Length Harvester in Northern Idaho.Master Thesis, University of Idaho.

14. Drews ES, Hartsought BR, Doyal JA, Kellogg LD (2001). Harvester-Forwarder and Harvester-Yarder Systems for Fuel Reduction Treatments.Int. Journal of Forest Engineering 12(1):81-91.

15. Dvorák J (2006). Tree damage after use of harvesters of intermediate 15 . performance. ForsttechnischeInformationen 1(2):5-7.

16. Dvořák J, Behjou FK (2011). Performance Standards of Medium- and High-Power Forwarders.Formec Austria.

17. Dvořák J, Malkovský Z, Macků J (2008). Influence of human factor on the time of work stages of harvesters and crane-equipped forwarders. Journal of Forest Science, 54(1):24-30.

18. Dvořák J, Cechner M (2006). Time snapshot of harvester technology used for advance felling and proposal of optimal production conditions. Formec Bulgaria.

19. Eliasson L (2005). Effects of Forwarder Tyre Pressure on Rut Formations and Soil Compaction. Silva Fenica 39(4): 549-557.

20. Eliasson L, Wästerlund I (2007). Effects of slash reinforcement of strip roads on rutting and soil compaction on a moist fine-grained soil. Forest Ecology and Management 252 (1/3):118-123.

21. Esteban T, Torrijos A, Vignote PS (2002). Productivity, cost and environmental effects of fully mechanisedthinningsonPinussylvestris L. planted stands in Spain. InvestigaciónAgraria, Sistemas y RecursosForestales 11(1):39-65.

22. Evanson T, McConchie M (1996). Productivity Measurements of Two Waratah 234 Hydraulic Tree Harvesters in Radiata Pine in New Zealand.Journal of Forest Science 7(3):41-52. 
23. Ewing RH (2001). Four evaluations of compact tracked harvesters and forwarders in commercial thinning. In: Advantage - Forest Engineering Research Institute of Canada (FERIC) 2(37):8.

24. Fulvio DF, Bergstrom D, Kons K, Nordfjell T (2012). Productivity and Profitability of Forest Machines in the Harvesting of Normal and Overgrows Willow Plantations. Croation journal of forest engineering 33(1):25-37.

25. Froese K (2004). Bulk Density, Soil Strenght, And Soil Disturbancce Impacts From A Cut-To-Lenght Harvest Operation In North Central Idaho. Master thesis -University of Idaho.

26. Gapsyte A (2003). Assessing damage to trees and soil in thinning's of pine stands. Baltic Forestry 9(1):69-74.

27. Gebauer R, Neruda J, Ulrich R, Martinkova M (2010). Soil Compaction - Impact of Harvesters' and Forwarders' Passages on Plant Growth.www.intechopen.com / 05.02.2013

28. Gerasimov I, Katarov V (2010). Effect of boogie track and slash reinforcement on sinkage and soil compaction in soft terrains. Croat.j. for. eng. 31(1): 34-45.

29. Gerasimov I, Seliverstov A, Syunev V (2012). Industrial Round wood damage and operational efficiency losses associated with the maintenance of the delimbing and feeding mechanism of a single grip harvesters. Formec Croatia.

30. Gerasimov I, Senkin V, Va“ätäinen K (2012). Productivity of single-grip harvesters in clear-cutting operations in the northern European part of Russia.Formec Croatia.

31. Ghaffarian MG, Stampfer K, Sessions J (2007). Forwarding productivity in Southern Austria .Croationjournal of forest engineering 28(2):169-175.

32. Glade D (1999). Single and Double-Grip Harvesters Productive Measurements in Final Cutting of Shelterwood. Int. Journal of Forest Engineering 10(2):63-74.

33. Glöde D, Sikström U (2001). Two Felling Methods in Final Cutting of Shelterwood, Single-Grip Harvester Productivity and Damage to the Regeneration. Silva Fennica 35(1):71-83.

34. Granhus A, Fjeld D (2001). Spatial distribution of injuries to Norway spruce advance growth after selection harvesting. Canadian Journal of Forest Research 31(11):1903-1913.

35. Grebner DL, Grace LA, Stuart W, Gilliland DP (2005). A Practical Framework for Evaluating Hauling Costs.Int. Journal of Forest Engineering 114-127

36. Gullberg T (1997). A Deductive Time Consumption Model for Loading Shortwood.Int Journal of Forest Engineering 8(1), 35-44.

37. Han HS, Page-Dumroese D, Han SK, TirockeJ (2006). Effects of Slash Mchine Passes and Soil Moisture on Penetration Resistance in a CTL harvesting.International journal of forest engineering 17(2):11-24.

38. Han SK (2006). Impacts On Soils From Cut-To-Lenght And Whole Tree Harvesting. Master thesis -University of Idaho.

39. Holzleitner F, Stampfer K, Ghaffaryan M, Visser R (2010). Economic Benefits of Long Term Forestry Machine Data Capture: Austrian Federal Forest Case Study. Formec Austria.
40. Hoss C, Jestaedt J(1991). Working time models for the use of harvesters. AFZ,AllgemeineForstZeitschrift 46(26):13581361.

41. Huyler NK, LeDoux CB (1999). Performance of a CTL harvester in a single tree and group selection cut. USDA Forest Service Pacific Research Station RP NE-711.

42. Jiroušek R, Klvač R, Skoupý A (2007). Productivity and costs of the mechanised cut-to-length wood harvesting system in clear-felling operations. Journal of Forest Science 53(10):476-482.

43. Jodlowski K (1999).Harvesting costs and tree damage in early thinnings of pine stands in Poland.Int. union of forest research organization.

44. Jori U, Maarit H, Lassi N, Jaakko K (2010).Assesing The Effect Of Harvesting Method On Soil Disturbances With a Spatial Harvesting Simulator. Formec Italy.

45. Kärhä K, Oy M (2004).Productivity and Cutting Costs of Thinning Harvesters.International Journal of forest Engineering 15(2):43-56.

46. Kellogg LD, Bettinger,P (1994). Thinning Productivity and Cost for a Mechanized Cut-to-Length System in the Northwest Pacific Coast Region of the USA. Int. Journal of Forest Engineering 5(2):43-54.

47. Klvac R, Skoupy A (2009).Characteristic fuel consumption and exhaust emissions in fully mechanized logging operations.Japanese forest journal and Springer 14:328334.

48. Labelle ER, Jaeger D (2011). Soil Compaction Caused by Cut-to-Length Forest Operations and Possible Short-Term Natural Rehabilitation of Soil Density.Soil science society of american journal 75(6):2314-2329.

49. Lambert MB, James OH (1990). Cost and Productivity of New Technology for Harvesting and In-Woods Processing Small Diameter Trees.USDA Forest Service, Pacific Research Station.

50. Lamminen S, Väätäinen K, Asikainen A (2011). The importance of the forwarder operator in loading phase during virtual CTL-forwarding.Formec Austria.

51. Landsber JD, Miller R, Anderson H, Tepp JS (2003). Bulk desity and soil resistance to penetration as affected by commercial thinning in NW Washington. USDA, Forest Service PNW-RP-551:1-43.

52. 51. Lars E, Torbjörn, B,Hagos L (2011). Productivity when forwarding fresh and dried logging residues.Formec Austria.

53. Limbeck-Lilienau, B (2003). Residual stand damage caused by mechanized harvesting systems. Proceedings of the Austro 2003 meeting, High Tech Forest Operations for Mountainous Terrain.

54. Lindroos 0, Wasterlund I (2011). Larger loads and decreased damage - the potentials of a new forwarding concept.Formec Austria.

55. Lindroos O, Wasterlund I (2012). Field study of a forwarder trailer concept - lower cost and fuel consumption at long distances.Formec Croatia.

56. Lineros PM, Espinosa BM, Jimenez RA (2003). Damage to residual Pinusradiata D. Don trees during commercial 
thinning with a harvester-forwarder system. Bosque 24(1):87-93.

57. Linhares M, Sette Junior CR, Campos F, Yamaji FM (2012). Harvester and forwarder machines efficiency and operational performance in forest harvesting. Pesquisa Agropecuária Tropical 42(2): 212-219.

58. Macku J, Dvorák J (2010). Time ExpenditureAnalysys Of Cut-To-Lenght Harvesters In Incidental Feelings Compared With Production Efficiency. Formec Italy.

59. Mali B, Košir, B (2007). Soil damage by harvesters and forwarders when cutting and skidding wood (CTLtechnology). GozdarskiVestnik 65(3):131-142.

60. Matangaran JR (2012). Soil compaction by Valmet operation at soil surface with and without slash. JMHT 18(1):52-59.

61. Matthies D, Weixler, H, Hess U (1995). Structural changes in forest soils caused by vehicle travel.AFZ/Der Wald, AllgemeineForstZeitschrift fur Waldwirtschaft und Umweltvorsorge 50(22):1218-1221.

62. Mizaras S, Sadauskiene L, Mizaraite D (2008). Productivity of harvesting machines and costs of mechanized wood harvesting: Lithuanian case study. Baltic Forestry 14(2):155-162.

63. McNeel JF, Ballard TM (1992).Analysis of site stand impact from thinning with a harvester forwarder system. In: International Journal of forest engineering 4(2):23-29.

64. Mederski PS, Bembenek M, Bandosz P, Karaszewski Z (2011). The impact of thinning intensity on forwarder loading.Formec Austria.

65. Mederski PS (2006). A comparison of harvesting productivity and costs in thinning operations with and without midfield. Forest Ecology and Management, 224(3): 286-296.

66. Meek P (1999). Factors affecting equipment productivity in commercial thinning.For.Eng. Res. Instit.of Canada 285:10

67. Moskalik T, Sadowski J (1998). Effects of harvesting machines and skidders on forest soils and remaining stands.ForstlicheForschungsberichteMünchen 174:7481.

68. Nicholls A, Bren L, Humphreys N (2004). Harvester Productivity and Operator Fatigue:Working Extended Hours. Int. Journal of Forest Engineering 15(2):57-65.

69. Nordfjell T, Athanassiadis D, Talbot, B (2003). Fuel Consumption In Forwarders. In: International journal of forest engineering 14(2):11-20.

70. Nordfjell T, Johansson L, Hellström J, Gref R, Skoupy A (2007). A Method to Measure Saw-Chain Lubrication. International Journal of Forest Engineeering 18(1):41-45.

71. Nugent C, Kanali C, Owende PMO, Nieuwenhuis M, Ward S (2003). Characteristic site disturbance due to harvesting and extraction machinery traffic on sensitive forest sites with peat soils. Forest Ecology and Management 180(1/3):85-98.

72. Nurminen T, Korpunen H, Uusitalo J (2006). Time Consumption Analysis of the Mechanized Cut-to-length Harvesting System. Silva Fennica 40(2):335-363.
73. Nuutinen Y, Vaatainen K, Heinonen J, Asikainen A, Roeser D (2008). The accuracy of manually recorded time study for harvester operation shown via simulator screen. Silva Fennica 42(1):63-72.

74. Porsinski T, Sraka M, Stankic I (2006). Comparison of two approaches to soil strength classification.Croatian Journal of Forest Engineering 27(1):17-26.

75. Posinski T, Pentek T, Bosner A, Stankic I (2012). Ecoefficient timber forwarding on lowland soft soils. www.intechopen.com / 20.01.2013.

76. Purfürst T, Lindroos 0 (2011). The Correlation between Long-Term Productivity and Short-Term Performance Ratings of Harvester Operators. Croatian Journal of Forest Engineering 32(2):509-519.

77. Richardson R, Gingras JF (1995). Shelterwood cutting and commercial thinning of softwood stands with the Valmet 701 harvester.For. Eng. Res. Inst. of Canada 5:2.

78. Rejšek K, Buchar J, Vanjcek I, Hromadko L,Vranova V, Marosz K (2011). Results of dynamic penetration test - an indicator of the compaction of surface soil horizons by forestry machinery. Journal of Forest Science 57(10):439450.

79. Rosnovskiľ IN (2001). Soil damage by summer logging in Western Siberia. Lesovedenie 2:22-26.

80. Sakai H, Nordfjell T, Suadicani K, Talbot B, Bollehuus E (2008). Soil compaction on forest soils from different kinds of tires and tracks and possibility of accurate estimate. Croatian journal of forest engineering 29(1):1527.

81. Sirén M (2001). Tree Damage in Single-Grip Harvester Thinning Operations. Journal of forest engineering 12(1):29-38.

82. Sirén M, Aaltio H (2003). Productivity and Costs of Thinning Harvesters and Harvester-Forwarders.In : International Journal of forest Engineering 14(1):39-48.

83. Spinelli R, Magagnotti N (2011). Productivity Norms for Harvesters and Processors used in Italy. Formec Austria.

84. Spinelli R, Visser R (2008). Analyzing and Estimating Delays in Harvester Operations. International Journal of Forest Engineering 19(1):36-41.

85. Stampfer K, Steinmuller T (2001). A new approach to derive a productivity model for the harvester Valmet 911 Snake. Int. Mountain Logging and 11th Pacific N-W Skyline Symosium.

86. Stankić I, Poršinsky T, Tonković I, Frntić F (2011). Development and implementation of productivity norms for forwarders in Croatia.Formec Austria.

87. Stankik I,Porsinsky T, Tomasic Z, Tonkovic I, Frntic M (2012). Productivity Models for Operational Planning of Timber Forwarding in Croatia.Croation journal of forest engineering 33(1):61-78.

88. Sutherland BJ (2003). Preventing soil compaction and rutting in the boreal forest of western Canada. Advantage $4(7): 1-53$.

89. Suwała, M, (1999). Efficiency and cost of harvesting in late thinning of Scots pine stands. In: Prace Instytutu Badawczego Leśnictwa 866/872:75-94. 
90. Suwała M (2003). Tree damage in pine stands resulting from wood harvesting in forest practice. Prace Instytutu Badawczego Leśnictwa Seria A 956/959:61-80.

91. Szewczyk G, Wojtala L (2010). The cost of timber harvesting with a harvester in stands under rebuilding with the use of partial cutting. Formec Italy.

92. Talbot B (2003). Assessing the Utility of two Integrated Harvester Forwarder Machine Concepts Through Stand Level Simulation. International journal of forest engineering 14(2):31-43.

93. Tsioras PA, Liamas DK(2010). Hauling Damages In a Mixed Beech Oak Stand. Formec Italy.

94. Tufts RA (1997). Productivity and cost of the Ponsse 15-series, cut-to-length harvesting system in southern pine plantations. Forest Products Journal 47(10):39-46.

95. Verani S (2001). Work times and productivity logging in a poplar stand with a forwarder. Mondo Macchina 10(11/12):50-56.

96. Visser R, Spinelli R (2011). Determining the shape of the productivity function for mechanized felling and fellingprocessing. Japanese Forest society and Springer 17:397402.

97. Wang Z, Greene D (1999). An Interactive Simulation System for Modeling Stands, Harvests and Machines. Journal of Forest Engineering 10(1):81-99.
98. Weise G (2002). Evaluation scheme for soil compaction by large machinery in the forest.Forsttechnische Informationen 1(2):10-12.

99. Wester F, Eliasson L (2003). Productivity in Final Felling and Thinning for a Combined Harvester-Forwarder (Harwarder).Int. Journal of Forest Engineering 2:45-51.

100. Wilpert K, Parbs J (1992). The area importance of soil damage during first thinnings with the combined use of mini-harvester and forwarders.Forsttechnische Informationen 44(4):25-28.

101. Wöll C, PórJónsson L (2009). Productivity and cost analysis of a harvester operation in Hallormsstaður, east Iceland. Report.

102. Wood M, Douglas AR (2006). The Taringatura Study: The Effects of Harvest Machine Traffic and Tillage on a Forest Soil in New Zealand. International Journal of Forest Engineering 17(1):53- 66.

103. Wood M, Moffat AJ, Carling PA (2003). Improving the Design of Slash Roads Used to Reduce Soil Disturbance During Mechanised Harvesting of Coniferous Forest Plantations in the UK. International Journal of Fores tEngineering 14(1):11-23.

104. Zimbalatti G, Proto AR (2010). Productivity Of Forwarders In South Italy. Formec Italy.

105. Zoric M (2012). Evaluation of forwarder multipassing on soil compaction. Formec Croatia. 